\title{
Trendy v porodech mimo partnerství
}

Martina Štípková

\section{Trends in Unpartnered Childbearing}

\section{Extended abstract:}

Single motherhood is known to have negative consequences on the wellbeing and life chances of mothers and their chiIdren. It appears as a consequence of parental dissolution or birth to an unpartnered woman. There are studies of divorce and union separation in the Czech Republic but less is known about women who bear their children outside unions. The goal of the paper is to determine if the proportion of mothers who bear children without having a partner changes in time and if there is a change in the socio-demographic characteristics of mothers. As the data on unpartnered childbearing are limited, the paper also aims to map the available data sources and their possibilities and limitations.

Two data sources are used to measure births to unpartnered mothers, the birth register (BR) and the Labour Force Survey (LFS). BR data include mothers of liveborn infants in 2007-2014 $(n=886,467)$ but do not contain a direct measure of family arrangement. Single mothers are defined as those who did not provide information about newborn's father. The LFS dataset is limited to households with a member under one year of age interviewed in 1993-2010 $(n=8,172)$. Single motherhood is defined as an absence of mother's partner in the household. Results about single motherhood are reported for all households and for those headed by one of the infant's parents.

The main independent variable is time period. Three maternal characteristics are controlled for, namely education, age, and parity.

The proportion of children with unidentified fathers declined slightly from about $10 \%$ in 2007 to $8 \%$ in 2014 . Both measures of unpartnered childbearing based on household composition suggest a growing trend in the 1993-2007 period and then stabilisation. The proportion of mothers without partners among all households with an infant rose from $7 \%$ (1993-1995) to $12-13 \%$ (2005-2010). As for households headed by child's single parent, the number of single mothers is underestimated because a substantial proportion of tem live in households headed by other persons. There is a growing trend from $3 \%$ to $8 \%$. These figures also indicate that the proportion of single mothers who live in their own households increased from 37\% (1993-1995) to 60\% (2008-2010).

Logistic regression was used to test if the trends apply to mothers in all socio-demographic groups. The results suggest that each of the measures of unpartnered motherhood is strongly associated with low (i.e. primary) education, first parity, and low or high age of mothers (up to 25 or above 35 y.o.). Interaction between time period and maternal characteristics shows that the decline in the non-identification of fathers occured in all groups of mothers except those with low (i.e. primary or vocational) education and those of third or higher parity. These groups show a growing tendency not to acknowledge fathers. The absence of fathers in households with infants exhibited a similar trend in all groups of mothers.

In sum, different definitions result in different estimates of unpartnered motherhood. Depending on the measure, the ratio of births outside unions was estimated between $8 \%$ and $12 \%$ at the end of the 2000 s (i.e. the time period of 2008-2010 when all of the time series overlap). Measurement based on the absence of father in any type of household provides the highest estimate of the proportion of unpartnered childbearing, while the other two measures lead to lower estimates. The results regarding temporal trends in unpartnered childbearing also depend on measurement. This suggests that the absence of coresident partner and denial of information about child's father are different events and they are likely to further differentiate in the future. The fact that the growing tendency to acknowledge paternity is not accompanied by higher numbers of coresident unions indicates a changing norm of fatherhood. The observed trends also imply that non-marital birth and the absence of paternal information, i.e. the two pieces of information recorded in the birth register, are becoming less and less informative regarding the composition of households of newborns. This makes future research more dependent on survey data.

Keywords: Czech Republic, education, non-marital childbearing, single mothers

http://dx.doi.org/10.13060/1214438X.2016.1.14.267 
Rodičovství bez partnera (ve velké většině případů se jedná o mateřství bez partnera) je náročnou životní rolí, ve které je třeba kombinovat ekonomické zajištění rodiny s péčí o děti a domácnost. Situace sólo matek ${ }^{2}$ a jejich možnosti kombinovat práci a péči se v různých zemích liší v závislosti na diskurzech a politikách spojených s mateřstvím či strukturou trhu práce [Duncan, Edwards 2013]. Ve většině zemí včetně ČR se však nesnadnost rodičovství bez partnera negativně projevuje na kvalitě života sólo matek i jejich dětí. Rodiny sólo matek jsou více ohroženy chudobou [Brady, Burroway 2012; Sirovátka et al. 2015] a zažívají více stresu [Amato 2000; Avison, Ali, Walters 2007; Osborne, Berger, Magnuson 2012]. Děti matek bez partnera mají v porovnání s dětmi s oběma rodiči v průměru horší fyzické či psychické zdraví [Bjarnason et al. 2012; Shah, Zao, Ali 2011; Śtípková 2013; Weitoft et al. 2003] a dosahují nižšího vzdělání [Hampden-Thompson 2009; McLanahan, Tach, Schneider 2013; Hubatková et al. 2012]. ${ }^{3}$

$\mathrm{K}$ rodičovství bez partnera vedou dvě cesty. Bud' zanikne vztah, do kterého se dítě narodilo, nebo se dítě narodí mimo jakékoli partnerství a již od počátku života je vychováváno pouze matkou. Okolnostem, které vedou $\mathrm{k}$ rozpadům partnerských vztahů, je v české sociologii a demografii věnována náležitá pozornost [viz např. Paloncyová, Štastná 2012; Pfeiferová 2009; Vohlídalová, Maříková 2011]. Mnohem méně toho ale víme o ženách, které rodí děti mimo partnerství. Doposud chybějící poznatky se pokusím částečně doplnit na následujicích stránkách.

Cílem tohoto textu je zjistit, jestli se v čase mění podíl matek, které rodí děti mimo partnerský vztah, a jestli se mění také asociace tohoto rodinného uspořádání se sociodemografickými charakteristikami matek. Rodinná uspořádání, do kterých se rodí děti, se v posledních více než dvou dekádách značně proměnila, a proto lze očekávat, že se změnil i podíl a/ nebo charakteristiky žen, které své děti rodí mimo partnerství. Jedním z důvodů, proč toho o porodech mimo partnerství víme tak málo, jsou omezené datové zdroje, ze kterých můžeme informace čerpat. Proto je cílem tohoto textu také zmapovat možnosti měření rodinného uspořádání rodiček a porovnat výsledky, která nám $\mathrm{k}$ tématu poskytují.

$\mathrm{V}$ následující sekci vysvětlím, že ženy, které rodí děti mimo partnerství, jsou obecně i v rámci sólo matek obzvláště zranitelnou skupinou. Dále shrnu poznatky plynoucí z dosavadního výzkumu zabývajícího se partnerským uspořádáním $\mathrm{v}$ době porodu a identifikuji mezery $\mathrm{v}$ dosavadním vědění. Poté představím metodologii a výsledky analýzy a na závěr shrnu výsledky výzkumu a předložím výhled pro další zkoumání na tomto poli.

\section{Proč se zabývat porody mimo partnerství v ČR}

Jak bylo zmíněno výše, sólo matky čelí řadě znevýhodnění a rizik vyplývajících z toho, že se musí postarat jak o ekonomické zajištění rodiny, tak o děti a domácnost. V oblasti placené práce jsou české matky obecně (tj. nejen samoživitelky) znevýhodněny z hlediska nezaměstnanosti, stability pracovních podmínek či výše dosažených příjmů [ČSÚ 2014a; Dudová, Hašková 2014; Hora 2009]. Tato rizika dopadají na sólo matky ve zvýšené míře, protože se nemohou spolehnout na př́jem partnera. Absence vydělávajícího partnera navíc vede k omezeným možnostem využití daňových úlev, které mají rodiny k dispozici [Hašková, Křǐ̌zová, Dudová 2015]. Není proto překvapivé, že rodiny matek bez partnera patř́i k těm, které jsou nejvíce ohroženy chudobou [Sirovátka et al. 2015]. Pro ženy, které partnera nemají už v okamžiku narození dítěte, je situace obzvláště složitá vzhledem k normě intenzivní mateřské péče a obvykle dlouhé mateřské přestávce v pracovní dráze a nedostatku služeb zajištujících péči o velmi malé děti [Hašková 2014].

Sólo matky jsou vystaveny velké psychické zátěži vyplývající z toho, že (téměř) veškerá zodpovědnost za výchovu a zajištění potřeb dětí je na nich [Dudová 2007]. Zátěž matek, které rodí mimo partnerství, je o to větší, že se jim ekonomické, psychické i instrumentální podpory partnera nedostává již v období těsně po narození dítěte, které bývá náročné i pro ženy žijící v páru. Dalším problémem je sociální stigmatizace mateřství bez partnera, která se projevuje už označováním rodin s jedním partnerem jako neúplných či rozvrácených. Sólo matky v této souvislosti často proživají pocity vlastní nedostatečnosti či selhání [Dudová 2007]. Další rovinou stigmatu spojeného se sólo mateřstvím je jeho asociace se zneuživáním sociálních dávek (přestože reálně je pro ně dominantním zdrojem financí placená práce [viz Dudová 2009; Hašková, Křížková, Dudová 2015]). Jedním z důsledků marginalizovaného statusu sólo matek je také nedostatečná artikulace jejich potřeb a zájmů při konstrukci sociálních politik [Cidlinská, Havelková 2009; Hejzlarová 2014]. Porod mimo partnerský vztah je navíc v porovnání s rozpadem vztahu až po narození dítěte spojen s větší mírou společenského odsouzení, protože je vnímán jako dobrovolně učiněná volba a projev nezodpovědnosti [Hejzlarová 2014].

\section{Trendy $\mathbf{v}$ rodinném uspořádání rodiček}

Po roce 1989 se rodinné chování značně proměnilo [pro přehled viz např. Sobotka et al. 2008]. Mezi nejvýraznější z těchto změn patři růst podílu dětí, které se rodí mimo manželství. Ten od roku 1989 vzrostl téměř šestinásobně, z $8 \%$ na 47 \% [ČSÚ 2014b]. Nárůst podílu neprovdaných matek se týkal především těch svobodných [Rychtaříková 2007]. Porod mimo manželství je tradičně typický pro ženy v mladém věku, s nízkým vzděláním a prvorodičky [Rychtaříková 2007, 2013; Štípková 2015]. Jeho asociace s nízkým věkem v čase posiluje [Rychtaříková 2007, 2013]. Souvislost mezi mimomanželským porodem a vzděláním matky se také měnila, i když trend není jednoznačný [Rychtaříková 2007, 2013; Štípková 2015].

Pokud ale analyzujeme trend $\mathrm{v}$ mimomanželských porodech, je třeba si uvědomit, že kategorie neprovdaných matek obsahuje dvě různé formy rodiny: ženy žijící v nesezdaném partnerství a ty, které partnera nemají. Jejich poměr se navíc v čase měnil. Na konci 80 . let byla většina neprovdaných matek bez partnera [Gbelcová, Koncerová, Možný 1990], ale později mezi nimi začaly převažovat matky žijící s partnerem [Hamplová 2007]. Srovnáváme-li tedy neprovdané matky před rokem 1989 nebo $\mathrm{v}$ raných 90. letech s recentními př́ipady, srovnáváme dvě odlišné skupiny matek. Bez dalšího zkoumání nelze říci, jestli trendy pozorované pro nesezdané mateřství obecně platí i pro mateřství bez partnera.

Dosavadní výzkum potvrzuje, že stejně jako nemanželské porody obecně jsou i porody mimo partnerství silně asociované s nízkým věkem a vzděláním matky [Hamplová 2007; 
Rychtaříková 2013]. Máme ale jen velmi omezené informace o počtu porodů mimo partnerství a jeho vývoji v čase. Podle výzkumu Sociální a ekonomické podmínky mateřství (SEPM) se mezi prvorodičkami v období 1995-2006 zvýšil podíl žen bez partnera z $10 \%$ na $17 \%$ [Hamplová 2007]. V roce 2002 $10 \%$ mladých rodičů do 35 let (otců i matek dohromady) udávalo, že se jim první dítě narodilo mimo partnerský vztah [Šalamounová, Nývlt 2006]. Analýza rodinných domácností Z období 2008-2012 ukazuje, že ženy bez partnera vedly 6-7 \% rodinných domácností s dítětem ve věku 0 let [Nývlt, Šustová 2014]. Vzhledem k odlišné metodice ale nelze údaje z těchto studií př́mo srovnávat.

\section{Metodologie}

\section{Zdroje dat a měření podílu mimopartnerských porodů}

Existující datové zdroje nabízejí tři způsoby, jak změřit podíl porodů mimo partnerství. Prvním z nich je použití údajů, které uvádějí rodičky pro matriční úřady při narození dítěte [viz např. Zeman 2007; Štípková 2015]. Druhým způsobem měření rodinného uspořádání rodiček jsou šetření domácností zachycující jejich strukturu [např. Nývlt, Šustová 2014]. Třetí možností je retrospektivní dotazování na partnerskou situaci v době porodu dříve narozených dětí [např. Hamplová 2007]. $\mathrm{V}$ tomto textu pracuji s prvními dvěma typy dat, konkrétně s údaji o narozených dětech z let 2007-2014 a s Výběrovým šetřením pracovních sil z let 1993-2010. ${ }^{4}$

Do analýzy vitální statistiky zahrnuji matky živě narozených dětí (n=886 467). Ve formuláři, který matky pro matriční úřady vyplňují, bohužel není př́imý dotaz na partnerské uspořádání matky. Na absenci partnerského vztahu ale můžeme usuzovat $v$ prípadě, že matka nevyplní údaje o otci dítěte, který pak není uveden v jeho rodném listě. Tento způsob měření podhodnocuje výskyt porodů mimo koresidenční partnerství. Uvedení otce dítěte totiž nutně neznamená, že spolu pár žije. Neuvedení údajů o otci má řadu závažných důsledků. Znemožňuje ustanovení vyživovací povinnosti otce, jeho práva na kontakt $\mathrm{s}$ dítětem nebo napřr. možnost, že po něm dítě zdědí majetek. Matce, která otce dítěte neuvede, mohou být také odepřeny některé sociální dávky, protože rezignace na požadování výživného po otci dítěte může být hodnocena jako nedostatečná snaha o zajištění př́ijmu rodiny [Soukupová 2007]. Lze proto předpokládat, že se $\mathrm{k}$ neuvedení otce dítěte uchylují matky, které mají velmi silný důvod zabránit tomu, aby otec dítěte $v$ jeho životě vůbec figuroval.

Výběrové šetření pracovních sil (VŠPS) je rotační panelový výzkum, ve kterém jsou dotazovány náhodně vybrané domácnosti vždy v pěti po sobě následujících čtvrtletích. Do analýzy zařazuji pouze domácnosti, ve kterých se vyskytuje dítě do jednoho roku věku, abych se tím co nejvíce přiblížila rodinné situaci v době narození dítěte. Měření složení domácnosti umožňuje přesnou identifikaci koresidenčního vztahu mezi matkou a otcem dítěte. Dotazování neprobíhá v okamžiku narození dítěte, ale až s větším či menším odstupem (do analýzy byly zahrnuty domácnosti, ve kterých žilo dítě ve věku 0 let, takže odstup mezi narozením a měřením struktury domácnosti může být až 11 měsíců). Není ale pravděpodobné, že by v této době docházelo ve složení domácností k výrazným změnám [srov. Chaloupková 2011]. Identifikace vztahů mezi členy domácnosti není v celém sledovaném období konzistentní. Do roku 2001 byl u každé osoby v domácnosti zaznamenán pouze její vztah k osobě v čele domácnosti (možnosti manžel/ ka či partner/ka, dítě, otec/matka, ostatní). Od roku 2002 je navíc pro každou osobu (tedy nejen osobu v čele domácnosti) zaznamenáno, zda v domácnosti žije její partner/ka, dítě a rodič. Starší měření vztahů v domácnosti neumožňuje určit přítomnost rodičů dítěte $\mathrm{v}$ případě, že domácnost nevede ani jeden $\mathrm{z}$ nich, ale například prarodič dítěte. Proto rozděluji analýzu dat VŠPS na dvě části.

První část analýzy se omezuje se pouze na domácnosti, v jejichž čele je bud' matka dítěte, nebo otec dítěte, který má v domácnosti partnerku (o které tak lze s velkou pravděpodobností předpokládat, že je matkou dítěte). Takových domácností je v souboru 7153. Za mateřství bez partnera jsou pokládány situace, kdy v čele domácnosti je matka dítěte a zároveň žádná osoba v domácnosti není jejím partnerem.

Druhá část analýzy VŠPS pracuje se všemi domácnostmi s dítětem ve věku 0 let a v př́ipadech, kdy v období 1993-2001 není v čele domácnosti rodič tohoto dítěte, je přitomnost rodičů dítěte odhadnuta. V naprosté většině se jedná o třígenerační domácnosti, v nichž žije alespoň jedno dítě hlavy domácnosti a vztah mezi dítětem ve věku 0 let a hlavou domácnosti patři do kategorie ostatní. Matka dítěte je identifikována jako žena ve věku 15-44 let, která je dcerou hlavy domácnosti nebo je k ní ve vztahu z kategorie ostatních. V př́ipadě, že je kandidátek na matku dítěte $\mathrm{v}$ domácnosti více (jedná se o 18 \% domácností, $\mathrm{v}$ jejichž čele není rodič dítěte), rozhoduje ekonomický status na mateřské nebo rodičovské dovolené. Otcové dítěte jsou identifikováni jako muži ve věku 15-44 let ${ }^{5}$, kteří nejsou bratry matky dítěte (tj. pokud je matka dítětem hlavy domácnosti, musí být vztah otce k hlavě domácnosti „ostatni“ a naopak). Tento postup vede $\mathrm{k}$ odhadu prítomnosti rodičů dítěte v $97 \%$ z 8411 domácností s dítětem ve věku 0 let. V období 20012010 můžeme srovnat odhad získaný tímto postupem s použitím přesných identifikátorů vztahů v domácnosti. Z tohoto srovnání vyplývá, že odhad vede k chybné identifikaci matky pouze v $1 \%$ domácností a k chybné identifikace otce ve $2 \%$ domácností. Celkový odhad podílu sólo matek je zkreslen o méně než jeden procentní bod. Můžeme proto odhad považovat za přijatelný.

Při výpočtu podílu matek bez partnera jsou data $\mathrm{v}$ obou částech analýzy vážena váhou zohledňující pohlaví, věk a okres bydliště matky.

\section{Vysvětlující proměnné}

Hlavní vysvětlující proměnnou je časové období. To je v př́ípadě dat $\mathrm{z}$ vitální statistiky měřeno jednotlivými roky v intervalu 2007-2014 a v datech VŠPS šesti tř́letými obdobími (19931995, 1996-1998, 1999-2001, 2002-2004, 2005-2007 a 20082010). Pro účely modelování jsou časové proměnné upraveny tak, aby nabývaly hodnot mezi 0 (začátek sledovaného období, tj. 2007 u narozených a 1993 v datech VŠPS) a 1 (konec sledovaného období, tj. 2014 u narozených a 2010 v datech VŠPS).

Kromě časového trendu se analýza zaměřuje na tři sociodemografické charakteristiky matek: vzdělání (základní, stř̌ední bez maturity, střední s maturitou a vysokoškolské), věk matky (do 25 let, 25-34 let, 35 a více let) a počet dětí (1, 2, 3 a více). Počet dětí je ve vitální statistice měřen jako biologické pořadí dítěte narozeného dané matce. $V$ datech VŠPS je měřen jako 
celkový počet dětí v domácnosti (nemusí se tedy nutně jednat o biologické děti matky, i když tomu tak ve většině případů zřejmě je).

\section{Trend $\mathrm{v}$ porodech bez partnera}

Tabulka 1 ukazuje, že podíl matek, které v letech 2007-2014 neuvedly do rodného listu otce dítěte, se mírně snižoval. V letech 2007-2008 bylo takových matek kolem $10 \%$ a postupně se jejich podíl snížil na $8 \%$ v roce 2014 . K největšímu meziročnímu snížení (o 1,4 procentního bodu) došlo mezi lety 2008 a 2009, kdy přestal platit nárok samoživitelek na prodloužené pobírání pěněžité pomoci v mateřství (PPM). Před touto změnou mohly samoživitelky čerpat PPM po 37 týdnů místo obvyklých 28 . Neuvedení otce $\mathrm{v}$ rodném listu bývá vnímáno jako dostatečný doklad o samoživitelství, které pak neni podrobováno dalšímu zkoumání [Soukupová 2007]. Je proto možné, že ženy bez partnera, které nastupovaly na mateřskou dovolenou před rokem 2009, mohla tato praxe ovlivnit při rozhodování o uvedení otce dítěte. Pokračování klesajícího trendu už ale podobně vysvětlitelné není. Zdá se tedy, že se snižuje počet žen, které rodí mimo partnerský vztah, a/ nebo rostouci podíl rodičů, kteří spolu netvoří pár, stojí o to, aby byl oficiálně ustanoven otcovský vztah $\mathrm{k}$ dítěti.

V tabulce 2 vidíme výsledky obou způsobů měření mimopartnerkých porodů $\mathrm{v}$ datech VŠPS. Mezi domácnostmi vedenými rodičem tvořily sólo matky v období 1993-2010 6 $\%$. Odhad zahrnující i domácnosti nevedené rodičem dítěte ale ukazuje téměř dvojnásobný podíl sólo matek (11\%). V období 2007-2010, kdy se časová řada dat z VŠPS a údaje z vitální statistiky překrývají, neuvedlo otce dítěte $\mathrm{v}$ rodném listu 9 $\%$ rodiček a s otcem dítěte nežilo $12 \%$ matek dětí ve věku 0 let. Podle očekávání tedy platí, že podíl matek, které nežijí s otcem dítěte, je vyšší než podíl těch, které neuvedou otce. Pokud bychom předpokládali, že matky, které neuvedou otce dětí, se rekrutují výhradně z těch, které s ním nežijí ve společné domácnosti, znamenalo by to, že pouze čtvrtina z nich údaje o otci poskytne.

Oba přístupy $\mathrm{k}$ identifikaci porodů mimo koresidenční partnerství v datech VŠPS dokumentují jeho nárůst $\mathrm{v}$ čase. Mezi domácnostmi vedenými jedním z rodičů dítěte podíl domácností sólo matek narostl ze 3 \% v období 1993-1995 na téměř 8 \% V období 2005-2007. V posledním období
2008-2010 se dále nezvyšoval. Pokud se zaměříme na všechny domácnosti, můžeme sledovat vzestup podílu sólo matek ze 7 \% v období 1993-1995 na necelých 13 \% v období 2005-2007 a poté stabilizaci na hodnotě $12 \%$. Nepřekrývající se intervaly spolehlivosti pro odhady na začátku a konci sledovaného období naznačují, že změna v čase je v obou prrípadech statisticky významná.

Srovnání obou časových řad také ukazuje, že narostl podíl samostatných domácností sólo matek s čerstvě narozeným dítětem. V období 1993-1995 bylo v čele domácnosti jen $37 \%$ sólo matek, zatímco v období 2008-2010 jich bylo již $60 \%{ }^{6}$

\section{(Ne)měnící se asociace mateřství bez partnera se sociodemografickými charakteristikami matek}

Platnost výše popsaných trendů pro všechny sociodemografické skupiny matek jsem zkoumala pomocí logistické regrese. Tabulka 3 ukazuje výsledky modelování pro každý ze tří způsobů měření porodů mimo partnerství. V prvním sloupci každého panelu vidíme poměry šancí odhadnuté v modelu, který obsahuje změnu v čase a tři sociodemografické charakteristiky matek. Tento základní model jsem poté postupně rozšiřovala o interakce mezi změnou v čase a jednotlivými sociodemografickými charakteristikami (pro každou z nich zvlášt; v jednom modelu je vždy pouze jedna sada interakčních koeficientů). Výsledky interakčních modelů jsou uvedeny ve druhém sloupci každého z panelů tabulky 3 . U každé kategorie vzdělání, věku a počtu dětí je uvedena změna v čase odhadnutá pro danou kategorii.

Výsledky základního modelu potvrzuji dř́vější zjištění o silné asociaci sólo mateřství s nízkým vzděláním. Pro všechny tři způsoby měření mateřství bez partnera platí, že největší šanci na toto rodinné uspořádání mají ženy se základním vzděláním. V porovnání se středoškolačkami s maturitou mají téměř 7,87krát vyšší šanci na neuvedení otce dítěte do rodného listu a $3,71 \mathrm{krát}$ vyšší šanci, že nebudou žít s otcem dítěte ve stejné domácnosti (resp. 3,40krát vyšší v prŕípadě, že sledujeme pouze domácnosti vedené rodiči dítěte). Srovnání matek se střední školou bez maturity a s maturitou ukazuje, že ty bez maturity mají zhruba dvakrát vyšší šanci na mateřství bez partnera. Naopak vysokoškolačky se sólo matkami stávají

\begin{tabular}{|c|c|c|c|c|c|c|c|c|c|}
\hline & 2007 & 2008 & 2009 & 2010 & 2011 & 2012 & 2013 & 2014 & Celkem \\
\hline Otec dítěte neuveden (\%) & 9.6 & 10.0 & 8.6 & 8.7 & 9.1 & 9.1 & 8.2 & 8.2 & 8.9 \\
\hline $\mathrm{N}$ & 112302 & 117171 & 115955 & 114699 & 106626 & 106588 & 104949 & 108177 & 886467 \\
\hline
\end{tabular}

\begin{tabular}{|c|c|c|c|c|c|c|c|c|c|}
\hline & 2007 & 2008 & 2009 & 2010 & 2011 & 2012 & 2013 & 2014 & Total \\
\hline Child's father unidentified (\%) & 9.6 & 10.0 & 8.6 & 8.7 & 9.1 & 9.1 & 8.2 & 8.2 & 8.9 \\
\hline $\mathrm{N}$ & 112302 & 117171 & 115955 & 114699 & 106626 & 106588 & 104949 & 108177 & 886467 \\
\hline
\end{tabular}


Tabulka 2. Trend v porodech bez partnera podle VŠPS (95\% intervaly spolehlivosti v závorkách)

$1993-1995 \quad 1996-1998$

\begin{tabular}{|c|c|c|c|c|c|c|c|}
\hline $\begin{array}{l}\text { V domácnosti nežije otec dítěte } \\
(\%)^{*}\end{array}$ & 7.0 & 9.9 & 9.8 & 11.2 & 12.5 & 12.1 & 10.6 \\
\hline & $(5.7 ; 8.2)$ & $(8.4 ; 11.3)$ & $(8.2 ; 11.4)$ & $(9.4 ; 13)$ & $(10.7 ; 14.3)$ & $(10.2 ; 13.9)$ & $(9.9 ; 11.2)$ \\
\hline $\mathrm{N}$ & 1589 & 1563 & 1286 & 1239 & 1311 & 1184 & 8172 \\
\hline
\end{tabular}

\begin{tabular}{|c|c|c|c|c|c|c|c|}
\hline \multirow{2}{*}{$\begin{array}{l}\text { Domácnosti obsahujićí dítě ve v } \\
\text { V čele domácnosti je matka bez } \\
\text { partnera (\%) }\end{array}$} & 0 let a & atku, & matko & o jejím & ierem & & \\
\hline & 3.0 & 5.0 & 5.3 & 6.2 & 7.9 & 7.9 & 6.1 \\
\hline & $(2.1 ; 3.9)$ & $(3.8 ; 6.2)$ & $(4.0 ; 6.7)$ & $(4.8 ; 7.7)$ & $(6.3 ; 9.4)$ & $(6.3 ; 9.6)$ & $(5.5 ; 6.6)$ \\
\hline $\mathrm{N}$ & 1367 & 1342 & 1110 & 1097 & 1156 & 1081 & 7153 \\
\hline
\end{tabular}

*V letech 1993-2001 je složení domácností, v jejichž čele není rodič dítěte ve věku 0 let, odhadnuté - viz sekci metodologie. Pozn.: Váženo podle věku, pohlaví a okresu bydliště matky.

Zdroj: VŠPS, vlastní výpočty

Table 2. Trend in unpartnered childbearing according to LFS** (95\% confidence intervals in brackets)

\begin{tabular}{|l|l|l|l|l|l|l|l|}
$1993-1995$ & $1996-1998$ & $1999-2001$ & $2002-2004$ & $2005-2007$ & $2008-2010$ & Total
\end{tabular}

\begin{tabular}{|c|c|c|c|c|c|c|c|}
\hline \multicolumn{8}{|c|}{ I households with mother and chil } \\
\hline $\begin{array}{l}\text { Father absent from household } \\
(\%)^{*}\end{array}$ & 7.0 & 9.9 & 9.8 & 11.2 & 12.5 & 12.1 & 10.6 \\
\hline & $(5.7 ; 8.2)$ & $(8.4 ; 11.3)$ & $(8.2 ; 11.4)$ & $(9.4 ; 13)$ & $(10.7 ; 14.3)$ & $(10.2 ; 13.9)$ & $(9.9 ; 11.2)$ \\
\hline $\mathrm{N}$ & 1589 & 1563 & 1286 & 1239 & 1311 & 1184 & 8172 \\
\hline
\end{tabular}

Households with mother and child under one year, headed by mother or her partner

\begin{tabular}{|l|c|c|c|c|c|c|c|c|}
\hline Headed by single mother (\%) & 3.0 & 5.0 & 5.3 & 6.2 & 7.9 & 7.9 & 6.1 \\
\hline & $(2.1 ; 3.9)$ & $(3.8 ; 6.2)$ & $(4.0 ; 6.7)$ & $(4.8 ; 7.7)$ & $(6.3 ; 9.4)$ & $(6.3 ; 9.6)$ & $(5.5 ; 6.6)$ \\
\hline $\mathrm{N}$ & 1367 & 1342 & 1110 & 1097 & 1156 & 1081 & 7153 \\
\hline
\end{tabular}

* Composition of households not headed by parent of child under one year has been estimated for the years 1993-2001 - see Methods section (in Czech).

** Labour Force Survey/ Výběrové šetření pracovních sil

Note: Weighted by age, gender and district of mother's residence.

Source: LFS, own calculations

nejméně často. Oproti středoškolačkám mají pouze zhruba $60 \%$ šanci, že budou mít dítě bez uvedeného otce nebo bez soužití s ním (poměry šancí jsou 0,58 pro neuvedení otce, 0,64 pro absenci otce $\mathrm{v}$ domácnosti a 0,55 pro absenci otce $\mathrm{v}$ domácnosti vedené jedním $\mathrm{z}$ rodičů).

Partnerská situace při porodu je také výrazně ovlivněna věkem matky. Matkami bez partnera se častěji stávají mladé ženy. Věk do 25 let znamená ve srovnání s kategorií 25-34 let zhruba dvojnásobnou šanci na neuvedení otce (poměr šancí 2,06) nebo absenci koresidenčního vztahu (poměr šancí 1,89). Pouze v prrípadě, že se zaměříme jen na samostatné domácnosti rodičů, není nízký věk asociován s vyšším rizikem sólo mateřství, což zřejmě souvisí s tím, že schopnost založit samostatnou domácnost je v tomto věku silně vázána na partnerství. Výskyt sólo mateřství je nejnižší ve věkové kategorii 25-34 let, ale poté opět roste. Matky ve věku 35 a více let mají v porovnání s prostřední věkovou kategorií o 27 \% vyšší šanci na neuvedení otce. Ještě výraznější je poměr šancí pro absenci partnera v domácnosti. Ten činí 2,27 pro všechny domácnosti a dokonce 3,29 mezi domácnostmi vedenými rodičem dítěte. Zvýšená tendence $\mathrm{k}$ sólo mateřství v pozdějším věku zřejmě souvisí s tím, že tyto ženy již nemají příliš mnoho času na realizaci svých reprodukčních plánů, a tak se pro porod rozhodnou i za okolností, které jim v mladším věku připadaly nevhodné (Slepičková a Bartošová [2008] např. ukázaly, jak zatím bezdětné ženy po třicítce postupně snižují kritéria kladená na partnera, případně i na samotnou existenci vztahu jako nezbytné podmínky mateřství).

Mateřství bez partnera je častější mezi prvorodičkami, a to zhruba dvakrát ve srovnání s druhorodičkami (poměry šancí se ve všech modelech pohybují mezi 1,83 a 1,97). U žen, které rodí dítě vyššího než druhého pořadí, je ve srovnání s druhorodičkami o polovinu vyšší tendence neuvádět otce do rodného listu. Na šanci na soužití s partnerem ale vyšší počet dětí nemá vliv.

V předchozí části analýzy jsme viděli klesající trend neuvádění otce dítěte do rodného listu. V základním modelu je tento trend vyjádřen poměřem šancí 0,89 (tj. šance na neuvedení otce se mezi lety 2007 a 2014 snížila o 11 \%). Interakční koeficienty ale ukazují, že tento pokles se netýkal všech skupin matek. Naprosto opačný trend je patrný u matek s nízkým vzděláním. U těch se základním vzděláním vzrostla ve sledo- 
vaném období šance na neuvedení otce více než čtyřnásobně. Tendence neuvádět otce dítěte mírně posílila i u vyučených matek (poměr šancí je 1,26) a u žen, které porodily dítě třetího či vyššího pořadí (poměr šancí 1,24). U žen s maturitou či vysokou školou je naopak mnohem výraznější růst tendence otce uvádět. Šance, že otec uveden nebude, se snížila o 31 \% u stř̌edoškolaček a o 55 \% u vysokoškolaček.

Základní modely odhadnuté na datech VŠPS popisují obecný trend jako 2,8násobné zvýšení šance (resp. 2,72násobné u samostatných domácností) na absenci partnera v domácnosti rodičky mezi lety 1993 a 2010. Modely, které zahrnují interakci mezi časem a sociodemografickými charakteristikami matek, nejsou ze statistického hlediska vhodnější než základní model. Můžeme tedy konstatovat, že tempo růstu šance na porod mimo partnerství bylo ve všech sociodemografických skupinách přibližně stejné. Když pomineme statistickou nevýznamnost rozdílů, posiluje tento závěr i fakt, že ve všech sociodemografických kategoriích jsou hodnoty poměru šancí indikující změnu v čase větší než $1, \mathrm{tj}$. v žádné skupině data nenaznačují, že by došlo k poklesu šance na porod mimo partnerství. Stojí ovšem za pozornost, že růst v čase vychází výrazně pomalejší u vysokoškolaček a matek nad 35 let a výrazně rychlejší u mladých matek. Statistická nevýznamnost těchto rozdílů může být způsobena nedostatečností dat. Vzorek kolem 8000 pozorování se sice zdá velký, ale při interagování malých kategorií (jako jsou např. mladé matky) je statistická síla omezená.

\section{Závěr}

Tento text se zabýval trendy v rození dětí mimo partnerství a jejich souvislostmi se sociodemografickými charakteristikami matek. Použity při tom byly dva datové zdroje a tři způsoby měření porodů mimo partnerství. Z výsledků vyplývá především to, že při použití různých metod měření můžeme dospět k odlišným odhadům podílu žen, které jsou po porodu dítěte bez partnera. Na konci první dekády 21. století se jejich podíl v závislosti na způsobu měření pohyboval mezi 8 a 12 \%. K nejvyššímu podílu matek bez partnera vede definice partnerství jako koresidenčního vztahu, bez ohledu na to, jestli matka či pár žije ve vlastní domácnosti nebo u př́ibuzných. Když se zaměříme pouze na domácnosti, ve kterých je matka či otec novorozeného dítěte $\mathrm{v}$ čele domácnosti, je výskyt matek bez koresidenčního partnera značně podhodnocený. Zdá se ale, že toto zkreslení s časem klesá, protože stále více matek bez partnera žije v samostatných domácnostech.

Výsledky také dokládají, že koresidenční partnerství a uvedení otce do rodného listu vykazují odlišný vývoj v čase. Podíl žen, které těsně po porodu nebydlely s partnerem, vzrostl v 90. letech a na počátku 21. století. Zhruba od roku 2005 se ale ustálil. Tento trend se týkal všech sociodemografických skupin. Data naznačují, že tempo růstu nemuselo být ve všech skupinách stejné, ale nezdá se, že by se asociace sólo mateřství s nízkým vzděláním a věkem matek jakkoli snížila. O podílu matek, jejichž dítě nemá v rodném listě uvedeného otce, máme informace až od roku 2007, nemůžeme tedy srovnat, jestli i pro ně platí rostoucí trend před rokem 2005. Podíl matek, které neuvedly otce dítěte, od roku 2007 až do současnosti mírně, ale setrvale klesá. Tento trend ovšem neplatí pro všechny sociodemografické kategorie. U žen s nízkým vzděláním naopak výrazně klesá šance, že údaje o otci dítěte uvedou.

Tyto trendy naznačují, že absence koresidenčního partnerství a neuvedení otce do rodného listu jsou dva odlišné jevy, které se do budoucna pravděpodobně budou dále diferencovat. Zvolna se zvyšující tendence ustavit legální vztah mezi otcem a dítětem, která není doprovázena růstem koresidenčních vztahů, naznačuje, že roste počet rodin, které chtějí udržovat vztahy mezi otcem a novorozeným dítětem, přestože rodiče nežijí ve společné domácnosti. To zřejmě odráží měnící se normu otcovství, která akcentuje nezprostředkovaný vztah mezi otcem a dítětem [srov. Dudová 2008]. Otázkou pro další výzkum je, jak funguji vztahy mezi otci a dětmi, které nemohou čerpat ze zkušenosti společného soužití, a do jaké míry se liší od vztahů po rozchodu rodičovského páru.

Jedním z důsledků popsaných trendů je, že vitální statistika, tedy data, která jsou zaznamenávána o všech narozených dětech, nám bohužel poskytuje stále méně přesné informace o složení rodin novorozenců. Data VŠPS ukázala, že zvyšování podílu porodů mimo partnerské soužití se po roce 2005 zastavilo, zatímco podíl porodů mimo manželství nadále roste [ČSÚ 2014b]. Porod mimo manželství tedy s postupujícím časem stále hůře identifikuje rodiny sólo matek. Zároveň analýza ukázala, že neuvedení otce stále méně vypovídá o koresidenčním vztahu mezi partnery. To značně limituje možnosti výzkumu, který se do budoucna bude zřejmě více spoléhat na výběrová šetření. 


\begin{tabular}{|c|c|c|c|c|c|c|}
\hline & \multicolumn{2}{|c|}{$\begin{array}{l}\text { Narození } \\
2007-2014\end{array}$} & \multicolumn{2}{|c|}{$\begin{array}{l}\text { VŠPS - domácnosti s dítětem } \\
\text { ve věku } 0 \text { let a jeho matkou } \\
2002-2010\end{array}$} & \multicolumn{2}{|c|}{$\begin{array}{c}\text { VŠPS - domácnosti s dítětem } \\
\text { ve věku } 0 \text { let a jeho matkou, } \\
\text { vedené rodičem dítěte } \\
1993-2010\end{array}$} \\
\hline & $\begin{array}{c}\text { Základní } \\
\text { model }\end{array}$ & $\begin{array}{l}\text { Interakce s } \\
\text { časem }\end{array}$ & $\begin{array}{l}\text { Základní } \\
\text { model }\end{array}$ & $\begin{array}{l}\text { Interakce s } \\
\text { časem }\end{array}$ & $\begin{array}{c}\text { Základní } \\
\text { model }\end{array}$ & $\begin{array}{l}\text { Interakce s } \\
\text { časem }\end{array}$ \\
\hline Změna v čase & 0.89 & & 2.80 & & 2.72 & \\
\hline \multicolumn{7}{|l|}{ Vzdělání matky } \\
\hline Základní & 7.87 & 4.29 & 3.71 & 2.25 (n.s.) & 3.40 & 2.67 (n.s.) \\
\hline Střední bez maturity & 2.16 & 1.26 & 2.00 & 3.07 (n.s.) & 2.24 & 3.72 (n.s.) \\
\hline Střední s maturitou (ref. kat.) & 1 & 0.69 & 1 & 3.18 & 1 & 1.97 \\
\hline Vysokoškolské & 0.58 & 0.45 & 0.64 & 1.80 (n.s.) & 0.55 & 1.58 (n.s.) \\
\hline \multicolumn{7}{|l|}{ Věk matky } \\
\hline Méně než 25 & 2.06 & 0.97 & 1.89 & 3.85 (n.s.) & 0.89 (n.s.) & 4.84 (n.s.) \\
\hline 25-34 (ref. kat .) & 1 & 0.85 & 1 & 2.36 & 1 & 2.63 \\
\hline 35 a více & 1.27 & 0.85 (n.s.) & 2.27 & 1.57 (n.s.) & 3.29 & 1.49 (n.s.) \\
\hline \multicolumn{7}{|l|}{ Počet dětí } \\
\hline 1 & 1.83 & 0.77 & 1.93 & 3.03 (n.s.) & 1.97 & 3.09 (n.s.) \\
\hline 2 (ref. kat .) & 1 & 0.94 & 1 & 2.49 & 1 & 2.65 \\
\hline 3 & 1.50 & 1.24 & 1.09 (n.s.) & 2.66 (n.s.) & 1.13 (n.s.) & 2.14 (n.s.) \\
\hline Konstanta & 0.03 & & 0.02 & & 0.01 & \\
\hline $\mathrm{N}$ & \multicolumn{2}{|c|}{855015} & \multicolumn{2}{|c|}{8172} & \multicolumn{2}{|c|}{7153} \\
\hline \multicolumn{7}{|c|}{ (n.s.) Rozdíl oproti referenční kategorii není statisticky významný na hladině významnosti 0,05. } \\
\hline \multicolumn{7}{|c|}{$\begin{array}{l}\text { Pozn.: Ve sloupci interakce s časem je uvedená změna v čase v dané kategorii vzdělání, věku či počtu dětí. Tyto poměry šancí byly odhadnuty v modelech, které } \\
\text { rozšiǐovaly základní model vždy o interakci mezi časem a dotčenou proměnnou. } \\
\text { Zdroj: Narození (ČSUU), VŠPS, vlastní výpočty }\end{array}$} \\
\hline
\end{tabular}

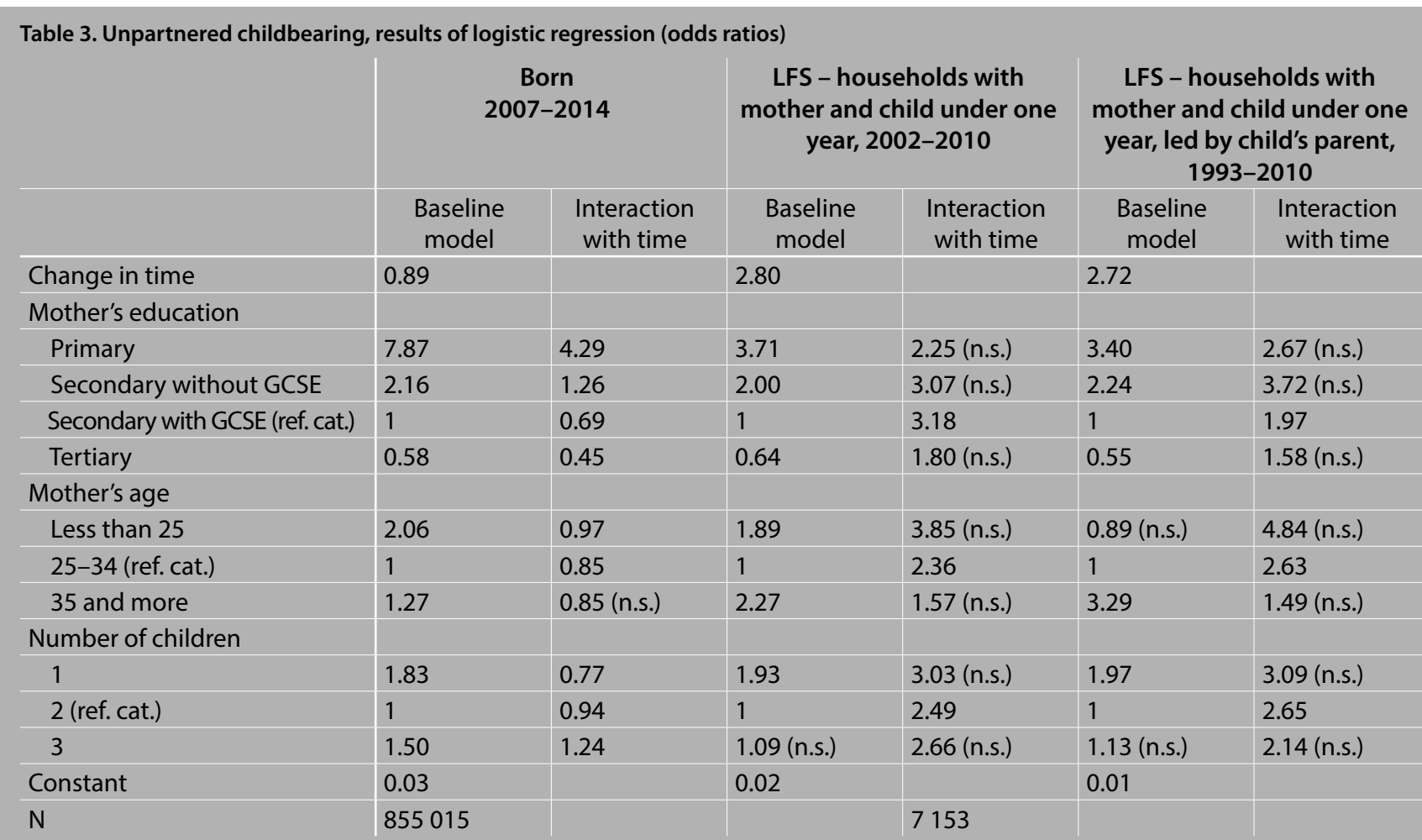

(n.s.) Difference from the reference category is not statistically significant at the 0.05 confidence level.

Note: The Interaction with time column shows change over time in the categories of education, age and number of children. These odds ratios were estimated in models that included, on top of the baseline model, interaction between time and the given variable.

Source: Birth statistics (CZSO), LFS, own calculations 


\section{literatura}

Amato, Paul R. 2000. „The Consequences of Divorce for Adults and Children." Journal of Marriage and Family 62 (4): 12691287, http://dx.doi.org/10.1111/j.1741-3737.2000.01269.x.

Avison, William R., Jeniffer Alli, David Walters. 2007. „Family Structure, Stress, and Psychological Distress: A Demonstration of the Impact of Differential Exposure." Journal of Health and Social Behavior 48 (3): 301-317, http://dx.doi.org/10.1177/002214650704800307.

Bjarnason, Thoroddur, Pernile Bendtsen, Arsaell M. Arnarsson, Ina Borup, Ronald J. Iannotti, Petra Löfstedt, Ilona Haapasalo, Birgit Niclasen. 2012. „Life Satisfaction Among Children in Different Family Structures: A Comparative Study of 36 Western Societies." Children \& Society 26 (1): 51-62, http:// dx.doi.org/10.1111/j.1099-0860.2010.00324.x.

Brady, David, Rebekah Burroway. 2012.,"Targeting, Universalism, and Single-Mother Poverty: A Multilevel Analysis Across 18 Affluent Democracies." Demography 49 (2): 719-746, http:// dx.doi.org/10.1007/s13524-012-0094-z.

Cidlinská, Kateřina, Barbara Havelková. 2009.„Genderové aspekty neúspěchu českých návrhů zákonů upravujících náhradní výživné na dítě." Gender, rovné přiležitosti, výzkum 11 (1): 60-73.

ČSÚ. 2014a. Zaostřeno na ženy a muže - 2014 [online]. Praha: ČSú [cit. 8. 11. 2015]. Dostupné z: http://tinyurl.com/zhn2rdf.

Čsú. 2014b. Česká republika od roku 1989 v číslech [online]. Praha: Čsú [cit. 8. 11. 2015].

Dostupné z: http://tinyurl.com/nb565yb.

Dudová, Radka. 2007. „Mateřství po partnerském rozchodu.“ Pp. 41-71 in Radka Dudová, Šárka Hastrmanová (eds.). Otcové, matky a porozvodová péče o děti. Praha: Sociologický ústav AV ČR, v.v.i.

Dudová, Radka. 2008. Otcovství po rozchodu rodičovského páru. Praha: Sociologický ústav AV ČR, v.v.i.

Dudová, Radka. 2009. „Práce jako řešení? Strategie obživy osamělých matek v ČR." Sociologický časopis 45 (4): 753-784.

Dudová, Radka, Hana Hašková. 2014. „Prekérní práce pečujících žen v kontextu ekonomické krize." Gender, rovné príležitosti, výzkum 15 (2): 19-32.

Duncan, Simon, Rosalind Edvards. (eds.). 2013. Single Mothers In International Context: Mothers Or Workers? London: Routledge.

Gbelcová, Eva, Jitka Koncerová, Ivo Možný. 1990.„Matky dětí narozených mimo manželství v Brně." Demografie 32 (1): 27-32.

Hampden-Thompson, Gillian. 2009. „Are Two Better than One? A Comparative Study of Achievement Gaps and Family Structure." Compare: A Journal of Comparative and International Education 39 (4): 517-534, http://dx.doi.org/10.1080/03057920802366372.

Hamplová, Dana. 2007. „Děti bez partnera nebo na psí knížku?" Pp. 49-58 in Dana Hamplová, Jana Chaloupková, Eva Soukupová, Petr Sunega, Kryštof Zeman (eds.). Děti na psí knižku. Praha: Sociologický ústav AV ČR, v.v.i.
Hašková, Hana. 2014. „Načasování a kombinování práce a péče o male děti." Pp. 183-208 in Hana Hašková (ed.). Vlastní cestou? Životní dráhy v pozdně moderní společnosti. Praha: Sociologické nakladatelství.

Hašková, Hana, Alena Kř́žková, Radka Dudová. 2015. Ekonomické náklady mateřství. Co znamená odpovědnost za péči o dítě/děti pro ženy z hlediska jejich pracovniho uplatnění a ekonomického postavení. Praha: Sociologický ústav AV ČR, v.v.i.

Hejzlarová, Eva M. 2014. „,Neviditelní"' aktéři v policy analysis." Sociální studia 11 (1): 109-129.

Hora, Ondřej. 2009. „,Situace rodičů s dětmi do sedmi let na trhu práce podle výsledků Výběrového šetření pracovních sil.“ Gender, rovné přiležitosti, výzkum 10 (2): 42-53.

Hubatková, Barbora, Martin Kreidl, Martina Štípková, Ladislav Rabušic. 2012. „Vliv rozvodu na vzdělanostní šance dětí.“ Pp. 178-193 in Jaroslava Hasmanová Marhánková, Martin Kreidl (eds.). Proměny partnerství. Životní dráhy a partnerství $v$ české společnosti. Praha: Sociologické nakladatelství.

Chaloupková, Jana. 2011. „Nejdříve dítě, potom svatba? Rodinné dráhy neprovdaných matek." Gender, rovné přiležitosti, výzkum 12 (2): 30-39.

McLanahan, Sara, Laura Tach, Daniel Schneider. 2013. „The Causal Effects of Father Absence." Annual Review of Sociology 39 (1): 399-427, http://dx.doi.org/10.1146/annurev-soc-071312-145704.

Nývlt, Ondřej, Šárka Šustová. 2014.„,Rodinná soužití s dětmi v České republice z pohledu výběrových šetření v domácnostech." Demografie 56 (3): 203-218.

Osborne, Cynthia, Lawrence M. Berger, Katherine Magnuson. 2012. „Family Structure Transitions and Changes in Maternal Resources and Well-Being." Demography 49 (1): 23-47, http://dx.doi.org/10.1007/s13524-011-0080-x.

Paloncyová, Jana, Anna Štastná. 2012.,„Sňatek a rozchod jako dva možné způsoby ukončení nesezdaného soužití." Demografie 54 (3): 214-232.

Pfeiferová, Štěpánka. 2009. „Nemožné soužití aneb Proč se rodiče rozcházejí. Pohled matek samoživitelek." Sociální studia 6 (4): 93-111.

Rychtaříková, Jitka. 2007. „Dvacet let svobodného mateřství v České republice (1986-2005).“ Demografie 49 (1): 1-12.

Rychtaříková, Jitka. 2013. „Děti narozené v manželství a mimo manželství: dvě různé populace." Demografie 55 (1): 4-26.

Shah, Prakesh S., Jamie Zao, Samana Ali. 2011. „Maternal Marital Status and Birth Outcomes: A Systematic Review and Meta-Analyses." Maternal and Child Health Journal 15 (7): 1097-1109, http://dx.doi.org/10.1007/s10995-010-0654-z.

Sirovátka, Tomáš, Ivana Šimíková, Robert Jahoda, Jana Godarová. 2015. Chudoba, materiální deprivace a sociální vyloučení $v$ České republice s dưrazem na děti a domácnosti vychovávající děti. Praha: Výzkumný ústav práce a sociálních věcí, v.v.i.

Slepičková, Lenka, Michaela Bartošová. 2008. „Problematické tranzice k mateřství." Sociální studia 5 (2): 35-54. 
Sobotka, Tomáš, Anna Štastná, Kryštof Zeman, Dana Hamplová, Vladimíra Kantorová. 2008. „Czech Republic: A Rapid Transformation of Fertility and Family Behaviour after the Collapse of State Socialism." Childbearing Trends and Policies in Europe, Book II: Demographic Research 19: 403-454.

Soukupová, Eva. 2007. „Neprovdané matky v sociálním systému." Pp. 79-97 in Dana Hamplová, Jana Chaloupková, Eva Soukupová, Petr Sunega, Kryštof Zeman (eds.). Děti na psí knižku? Mimomanželská plodnost v ČR. Praha: Sociologický ústav AV ČR, v.v.i.

Šalamounová, Petra, Ondřej Nývlt. 2006. „Mimomanželská plodnost - současné trendy v Evropě." Pp. 118-140 in Dana Hamplová, Petra Šalamounová, Gabriela Šamanová (eds.). Životní cyklus. Sociologické a demografické perspektivy. Praha: Sociologický ústav AV ČR, v.v.i.

Štípková, Martina. 2013. „Declining Health Disadvantage of Non-marital Children: Explanation of the Trend in the Czech Republic 1990-2010." Demographic Research 29: 663-706.

Štípková, Martina. 2015. „Ideational and Economic Causes of the Rise in Non-Marital Childbearing in the Czech Republic." European Journal of Population 31.
Vohlídalová, Marta. 2014. „Cesty k (ekonomické) soběstačnosti žen po rozvodu a rozchodu." Pp. 209-230 in Hana Hašková (ed.). Vlastní cestou? Životní dráhy v pozdně moderní společnosti. Praha: Sociologické nakladatelství.

Vohlídalová, Marta, Hana Mař́ková. 2011.„,Rozpady kohabitací, rozvody manželství: jiné a/nebo stejné sociální fenomény?" Gender, rovné príležitosti, výzkum 12 (2): 3-15.

Weitoft, Gunilla R., Bengt Haglund, Anders Hjern, Måns Rosén. 2003. ,"Mortality, Severe Morbidity, and Injury in Children Living with Single Parents in Sweden: a Population-based Study." The Lancet 361 (9354): 289-295, http://tinyurl.com/joeanpw.

Zeman, Kryštof. 2007. „Nemanželská plodnost - demografický přehled." Pp. 17-27 in Dana Hamplová, Jana Chaloupková, Eva Soukupová, Petr Sunega, Kryštof Zeman (eds.). Děti na psí knižku? Mimomanželská plodnost v ČR. Praha: Sociologický ústav AV ČR, v.v.i.

\footnotetext{
Martina Štípková absolvovala doktorské studium sociologie na Fakultě sociálních věk UK a magisterské studium demografie na Autonomní univerzitě v Barcelonè. Působí jako odborná asistentka na katedře sociologie Filozofické fakultuy Západočeské univerzity v Plzni. Ve svém výzkumu se věnuje vzájemným souvislostem mezi rodinným chováním, sociálními nerovnostmi a zdravím. V posledních letech jí vyšly články v časopisech Demographic Research, European Journal of Population či v Sociologickém časopise/Czech Sociological Review. Lze ji kontaktovat na adrese: marsti @kss.zcu.cz
}

\section{poznámky}

\footnotetext{
Tento text vznikl za podpory Motivačního systému Západočeské univerzity v Plzni, část Postdoc.

2 Termíny sólo mateřství, mateřství bez partnera a samoživitelství jsou v textu používány jako synonyma. Nicméně dávám přednost prvním dvěma termínům, protože nejsou tak silně asociovány s ekonomickou stránkou věci jako samoživitelství.

${ }^{3}$ Sólo mateřství nemusí nutně přinášet jen znevýhodnění či rizika. $\mathrm{Na}$ životy řady žen může mít mateřství mimo partnerský vztah pozitivní dopad, např. v oblasti osobní autonomie nebo sebevědomí plynoucí z toho, že svou náročnou situaci zvládly [Dudová 2007; Vohlídalová 2014]. Výše citované studie ale naznačují, že případy, kdy jsou na tom rodiny sólo matek (zejména jejich děti) z různých hledisek hưre, bohužel převažují.

${ }^{4}$ Retrospektivní data o sólo mateřství v době narození dítěte jsou dostupná např. v šetření ISSP Rodina 2002 nebo v Generation and Gender Survey (GGS) 2005, ale z následujících důvodů jsem je do analýzy nezařadila. Vzorek šetření ISSP 2002 není dostatečně velký, aby umožnil analýzu časového trendu. Šetření GGS má sice dostatečný počet pozo-
}

rování, ale výsledky jsou při porovnání s podílem mimomanželských porodů zaznamenaným ve vitální statistice nerealistické. $V$ dotazníku nebyl pokládán prímý dotaz na partnerskou situaci v době porodu. Místo toho byla partnerská a reprodukční historie respondentů zjištována zvlášt'. Došlo zřejmě k tomu, že respondenti si sice dobře vybavili, kdy se jim narodily děti, ale neuvedli některé vztahy, zejména ty ze vzdálenější minulosti, což vedlo $\mathrm{k}$ nadhodnocení počtu porodů mimo partnerství. Šetření Sociální a ekonomické podmínky mateřství 2006 bylo již zpracováno jinde [Hamplová 2007] a navíc se nezaměřuje na všechny rodičky, ale pouze na ty, které porodily první dítě mimo manželství.

${ }^{5} \mathrm{U}$ mužů teoreticky nemusíme omezovat věk shora, ale prakticky je velmi málo pravděpodobné, že by otec ve středním a vyšším věku nežil ve vlastní domácnosti.

${ }^{6}$ Tyto údaje jsou odvozeny z Tabulky 2. Např. v prvním časovém období byl celkový počet domácností sólo matek 111 (7 \% z 1589), přičemž mezi domácnostmi vedenými rodičem dítěte jich bylo identifikováno pouze 40 (3 \% z 1367), tj. 37 \% z celkových 111 domácností sólo matek. 